\title{
自律分散型電圧無効電力制御システム高度化を目指した $\mathrm{NN}$ 法による地域需要予測法の開発
}

\author{
学生員 鈴木 修* 正 員 只 国紅* \\ 正員皆川保*
}

\author{
A Regional Demand Forecast by NN Method for Distributed Autonomous Voltage \\ and Reactive Power Control System
}

Osamu Suzuki*, Student Member, Guohong Wu*, Member, Tamotsu Minakawa*, Member

\begin{abstract}
This paper describes technology required for advanced intelligent voltage and reactive secondary control systems enabling co-ordination of voltage control between main and local power systems. Firstly, the paper describes the general structure of a power system control and the concept of a proposed autonomous voltage and reactive power control system. Then, the paper comments on the inadequate behavior of voltage and reactive power control systems, such as up-and-down fluctuations, which sometimes occur during off-peak load times, and explains the reasons for voltage fluctuations. The capacity of distributed generation is increasing in accordance with deregulation of electric supply. In order to enhance voltage stability of power system, the voltage control system requires the more detail information and data of its local network systems, such as local demand forecast, distributed generation and characteristics of power systems. The paper briefly describes two previously developed intelligent component functions, namely, flexible feed forward control to prevent voltage fluctuation, and on-line acquisition of voltage characteristics by neural network technology. The paper describes local demand forecasting one or two hours in advance by the NN method. This method is also applicable to the forecast of the total demand of a power system.
\end{abstract}

キーワード : 電圧無効電力制御, 主幹·二次系統の協調, 電力自由化, 分散電源, $\mathrm{NN}$ 法, 電力系統制御

Keywords: voltage and reactive power control, coordination of main and local power system control, deregulation, distributed generation, neural network, control of power systems

\section{1. はじめに}

電力系統電圧無効電力自動化制御システム $(\mathrm{AVQC})$ は 1960 年代頃から開発・実用化が進められてきたが，如何な る系統でも通用する汎用システムはまだ存在しない。本論 文は，先ず電圧無効電力制御の問題を明らかにし，次いで， 汎用 AVQC を実現するために必要な基本要素機能の内容に ついて述べる本論文か対象とする領域と自動制御機能は 次の通り。

対象機器と領域: 平常時と事故時では制御する主要機器と 手法が異なる。本論文か対象とするものは平常時系統運用 制御のために使用される機器で発電機, 大容量発電機昇圧用 変圧器および变電所変圧器の負荷時タップ切換器 (OLTR), 分路リアクトル (Sh.R), 電力用コンデンサー $(\mathrm{SC})$ およ

\footnotetext{
東北学院大学工学部

干 985-8537 宮城県多賀城市中央一丁目 13

Tohoku Gakuin University

13, Chuo-Ichome, Tagajyo, Miyagi-ken 985-8537
}

びSVC 等である。また対象運用操作は次の通り。

(i) 年末〜正月, 5 月連休，8 月お盆等の期間中の電圧 過昇問題 : 一部の超高圧 (EHV) 送電線停止, 平行 2 回線 の 1 回線停止, 地中ケーブル系統停止等の進相電流低減操 作が不可欠。これらには週間系統運用計画検討結果に基づ き事前に手動操作する。従って，この領域は本論文の対象 としていない。

(ii) 平常時の系統電圧は安定しているが, 一部の局地 的電圧不安定現象が発生すると急速に不安定現象が全系統 に波及する事がある。また，平常運転時でも突然，電圧無 効電力自動制御機器が動作して交互に電圧上昇と下降を繰 り返す不適正なハンチング現象が発生することもある。本 論文はこの領域の問題解決と統合 AVQC 体系の確立を目的 とする。

\section{AVQC の課題と提案する自律分散型システム 構成体系の概念}

〈2. 1〉AVQC システムの基本的技術課題 AVQCに 
関する未解決の基本的技術課題を以下に列記する ${ }^{(1)}$ 。

・AVQC システムには周波数制御 (LFC) の樣な広く認 知された制御ブロック図が無い

・目的関数についても広く認知されたものが無い

-電力自由化の進展に伴い 2 次系統や配電系統に接続さ れる分散電源か増大しつつあり，系統の電圧特性に大 な変化をもたらす。然るに分散電源の運転状態を正確 に把握することは困難である。従って，従来の樣な制 御方式では的確に制御できなくなる可能性がある。こ の対策としては数時間先のローカル系統の需要想定と 分散電源量を自律的に予測できる機能の保有が必要で ある。

・必要かつ重要なデータが他業務システムに大きく依存。 事例: 系統構成 (遮断器, 断路器等のデータ), 発電機 並解列計画情報，需給計画，状態推定 (SE) 等のデータ ・計測データ送受信通信容量の不足

〈2 2〉自律分散型 AVQC システム構成体系の概念 他 電力系統との連系が進められた 1960 年代頃から統合系統 制御方式 (EMS) の開発導入進められた。即ち, LFCでの 連系線潮流偏差バイアス周波数制御 (TBC) は地域 Block 単位とした自律分散制御である。一般に系統連系規模が大 きくなると各地域ブロック系統の制御機能を高度化しない と系統全体の協調が取れず制御系全体が崩壊する危険性が 増大する。

EMS の一部である AVQC の系統電圧のハンチング現象 防止には電圧感度特性 $(\Delta \mathrm{V} / \Delta \mathrm{Q})$ を自動的に把握すること が不可欠である。この対策として次の 2 通りの方法がある。

(i ) 電圧無効電力自動調整装置 (AVQR) 設置電気所は 中央給電指令所や支店給電指令所等の EMS から電圧感度 特性計算結果を送信してもらい制御する。

(ii ) 何等かの方法で主幹系統側および所属支店系統の 電圧感度特性を自律的に把握する。

前者の方法では電圧感度特性計算を実施する以前に EMS 構成機能のSE (State Estimation) を動作させ, 光の計算結 果を電圧感度特性計算に受け渡す必要がある。現在，中給 EMS の SE は 5 分に 1 回程度実施されている。電圧感度特 性計算は速くても 10 分に 1 回程度である。従って, 電圧 感度特性を AVQC に受け渡すのは 10〜15 分に 1 回程度が 限度である。然るに，電圧崩壊現象防止対応には秒単位の 即応性が要求される。また, 経済性および保守性にも問題 がある。

従って, ローカルな電圧不安定現象の危険がある時には 上位指令機関からの制御信号を待たずに発変電所機器が適 切な動作を発動できないと電圧崩壊を防げない。

提案する自律分散型 AVQC , AVQR は現場の制御装置を Intelligent 化により自律的応動機能を強化し，系統全体と の協調を取る。図 1 は EMS 体系の全容を示す。

図 1 に関連する各機能の役割は次の通り。

SCADA ; オンライン系統設備運転データ収集の送受信 装置。

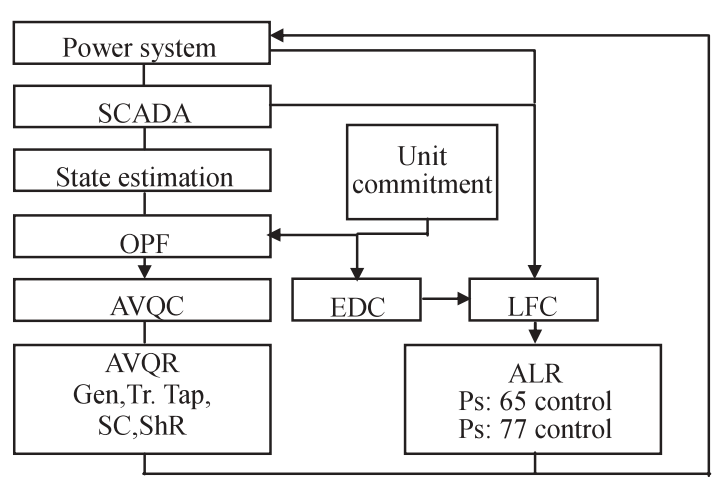

図 1 電力系統自律分散型システム構成図

Fig. 1. Autonomous control configuration of LFC and AVQC.

State Estimation（状態推定）；系統設備機器の運転状態 計測データを一定時間毎に評価検定し, 各種 EMS 制御機 能に基礎データを受け渡す。計算処理としてはかなり大き い負荷である。 5 分間隔程度の結果のデータを供給するの が限度。

OPF( 最適潮流計算)；全系統運用最適化 (P，Q，V 等の 適正化，燃料費最小化，安定度制約維持等の計算を実施)。 また, 主幹系統及び 2 次系統との制御目標值を計算し，関 係制御機関に送信する。20 30 分間に 1 回程度解析結果の 提供か限度。

ELD（経済負荷配分）; 翌日及び当日経済運用スケジュー ル計画計算

EDC（経済負荷配分制御）；ELD 結果に基づき対象発電 機出力を約 5 10 分程度の出力変化に対するオンライン制 御。制御信号は LFC 制御と共用 (発電機ユニット毎に LFC か EDC かの対象を定めている)。

$\operatorname{AVQC}($ 電力系統電圧無効電力自動化制御システム), $\operatorname{AVQR}$ ( 自動電圧無効電力調整装置); 上記諸機能から情 報を受け中給, 支店給の AVQC は担当系統内の制御機器 の目標値を計算して各発変電所の AVQR に制御目標デー タを送る。AVQR はこの情報と自己か収集した情報を基に 自律的に判断して変圧器の Tap, SC, ShR 等を制御する。 AVQR は高度にIntelligent 化し，系統特性を自律的に把握 して不要な V，Qの上下動を防止する機能を保有させる。

LFC( 周波数制御)；中給 LFC 装置は周波数と連系線潮 流を目標值に近づけるため, 各発電機出力に制御信号を送 信する。

65 control ; ガバナフリー運転（主として水力と一部の 火力)

77 control ; ロードリミッター運転（主として火力）

Unit commitment ; 発電機の起動停止スケジュール

ALR（自動負荷制御装置）; 中給からの制御信号を受けて 発電機の出力を自動調整する装置。EDC, LFC 信号に応じ てガバナフリー (65) 制御 , あるいはロードリミッター (77) 制御により調整する。

〈2. 3〉提案する自律分散型 AVQC システム体系の概念 電力自由化の進展は二次系統や配電系統に並列される分 
散 電源の増大をもたらすことは必須である。分散電源に起 因する電圧変動は原則として他系統に影響を及ぼさない樣 にローカル的に敏速に対処すると同時に, 上位系統との協 調をとれるようにしなければならない。このためにはロー カル系統の需要，分散電源の運転状況および系統電圧特性 等の変化を全て中央給電指令所, 支店給電指令所または制 御所のシステムが検出, 判断してから送信される制御信号 を待ってから応動するのでは電圧崩壊を防ぐタイミングを 失うことになる。また，これらの業務を集中的に実施する ことは業務内容および業務量等の事由から困難である。

$\mathrm{AVQC}$ 問題解決には発変電所に設置された AVQR 装置 が自所の電圧, 需要, 系統電圧特性および電力潮流等の時 系列変化を検出すると共に関連するローカルの需要，電圧 無効電力等のデータを受信し，マクロ的状況判断を的確に 行い, 自律的に応動できる機能の保有 (intelligent 化) が必 要である。

以上の諸要件を勘案して発変電所に分散配置されている電 圧無効電力制御装置を高度にインテリジェント化して $0.5 \sim 1$ 時間先の需要，電圧変化，系統特性等々を自律的に予測し， 系統電圧無効電力の協調制御を自動的に実施出来るシステ 么の開発を志向した。図 2 は従来方式と新方式の AVQC シ ステムとの制御ブロック図の相違を判り易く対比図解した ものである。本論文はローカルの需要予測方法に関するも ので分散電源量予測方法は, 今後，研究開発する。

\begin{tabular}{|c|c|c|c|c|}
\hline & Conven & nal AVQC & \multicolumn{2}{|c|}{ Proposed New AVQC } \\
\hline \multirow{4}{*}{$\begin{array}{l}\text { Block } \\
\text { diagram }\end{array}$} & $\begin{array}{c}\text { CLDC \& } \\
\text { RLDC }\end{array}$ & $\begin{array}{c}\text { Ps \& } \\
\text { Substations }\end{array}$ & $\begin{array}{c}\text { CLDC \& } \\
\text { RLDC }\end{array}$ & $\begin{array}{c}\text { Ps \& } \\
\text { Substations }\end{array}$ \\
\hline & AVQC & AVQR & $\mathrm{AVQC}$ & AVQR \\
\hline & $\begin{array}{l}\text { Demand } \\
\text { forecast }\end{array}$ & & $\begin{array}{l}\text { Demand } \\
\text { forecast }\end{array}$ & $\begin{array}{l}\text { demand } \\
\text { forecast }\end{array}$ \\
\hline & & & & $\begin{array}{l}\text { Distributedi } \\
\square \text { generation } \\
\text { [orecast } \\
\text { forecast }\end{array}$ \\
\hline
\end{tabular}

Note: CLDC: Central Load Dispatching Center, RLDC: Regional Load Dispatching Center, Ps: Power Stations

図 2 従来型および提案する AVQR の制御ブロック図比較 Fig. 2. Comparison of the control block diagrams between conventional and proposed AVQC systems.

\section{3. これまでの研究成果}

〈3. 1〉ハンチング現象の発生原因究明と対策 変圧器 OLTR のハンチンク現象の原因を図 3 に図解する ${ }^{(5)}$ 。この 图では 1 タップ当たり電圧変化が目標電圧幅より大きいた めタップが上下方向に繰り返し動作する。これを防止する ためには目標電圧幅を広げる必要がある。

1 タップ当りの電圧変化量 $\Delta \mathrm{V} / \mathrm{tap}$ を推定し, 図 4 のよう に目標範囲上下限に適切な量のファジー領域を付け足せば ハンチンク現象を防止できる。

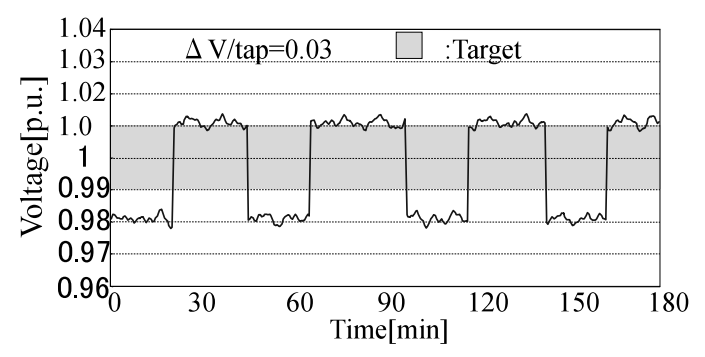

図 3 従来手法によるハンチング発生事例

Fig. 3. The case of tap changer hunting phenomena by conventional method.

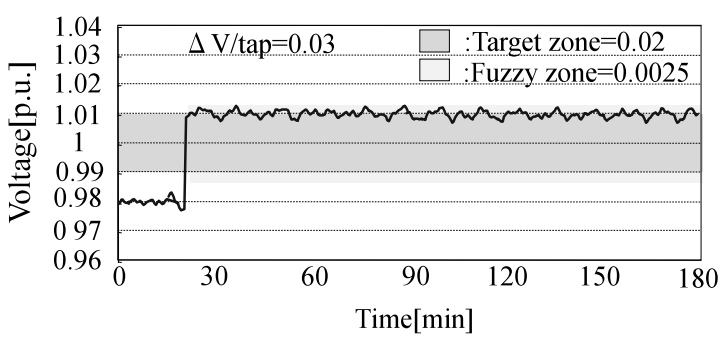

図 4 予測先行型 AVQC によるハンチング防止事例

Fig. 4. The preventing case of hunting phenomena by improved AVQC system.

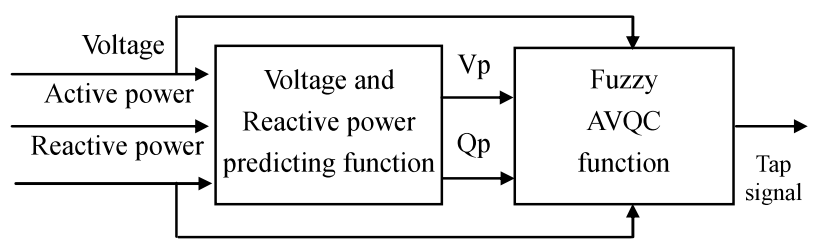

$\mathrm{Vp}$; 電圧予測值 $\mathrm{Qp}$;無効電力予測值

図 5 AVQC ファジーエキスパート制御システム 構成ブロック図

Fig. 5. A block diagram of AVQC Fuzzy-Expert system (AVQC).

筆者等は東北電力能代火力 1 号機昇圧変圧器 OLTR 制御 にAVQC ファジーエキスパート制御システムを初めて開発 実用化したが，弚の機能構成ブロック図を図 5 に示す(2)(3)。

本論文で提案する新 AVQC はこの基本機能をべースに 種々な機能を付加することにより高機能のシステムを構築 するものである。これまでに,開発した機能は次の通り(5)(6)。

(1) 5 10 分程度の周期的変動現象対策

(2) 電圧感度特性 (短絡容量) 変化の NN 法による推定

〈3. 2) 予測先行型 AVQC 制御手法系統特性変化時 に電圧変動周期が 5 10 分周期程度の比較的小さい電圧八 ンチンク現象を防止するため，単位制御量当たりの $\Delta \mathrm{V} / \Delta \mathrm{Q}$ 特性 (Tr.Tap の場合は 1 tap 当たりの $\Delta \mathrm{V}, \Delta \mathrm{Q}$ ) に応じて目 標範囲を拡大して不適正動作を防止する方法を開発した ${ }^{(5)}$ 。

〈 3. 3〉 $\Delta \mathbf{V} / \Delta \mathbf{Q}$ 特性のオンライン自動推定 ${ }^{(5)} \quad \Delta \mathrm{V} / \Delta \mathrm{Q}$ 特性は短絡容量と強い相関を持つため, 短絡容量と相関の 強いデータを NN の入カデータとして選定する。総需要が 大きい時は並列される発電機総出力も大きく短絡容量も大 
きくなる。また，送電損失も大きくなる。系統の総需要と 当該支店の需要を入力とする。更に, 短絡容量は系統構成 とも密接な関係を持っている。実際の電力系統運用業務で は系統運用操作要綱で平常の標準系統構成パターン (1 ま たは 2 パターン程度)，事故時系統構成パターン ( 3 から 6パターン程度) 等のように類型化した系統構成パターン を定義し，定められた運転・操作手順に基づき系統運用を 行っている。これらの系統構成パターンコードは光れ攵れ の地域の系統構成および並列発電機状況の情報も含むもの であるため当該制御地点の短絡容量の情報を示すものであ る。この理由から本研究では系統構成パターンコードを入 カデータとした。更に，実際にTr.Tap を操作した時の V ， $\mathrm{Q}$ 計測データから $\Delta \mathrm{V} / \Delta \mathrm{Q}$ 特性を自動的に計算して，NNで On-line 学習結果を蓄積することにより， $\Delta \mathrm{V} / \Delta \mathrm{Q}$ 特性を自 律的に推定できる分散型の電圧無効電力制御システムの開 発を行った。本方式に用いる NN 構成を図 6 に示す。

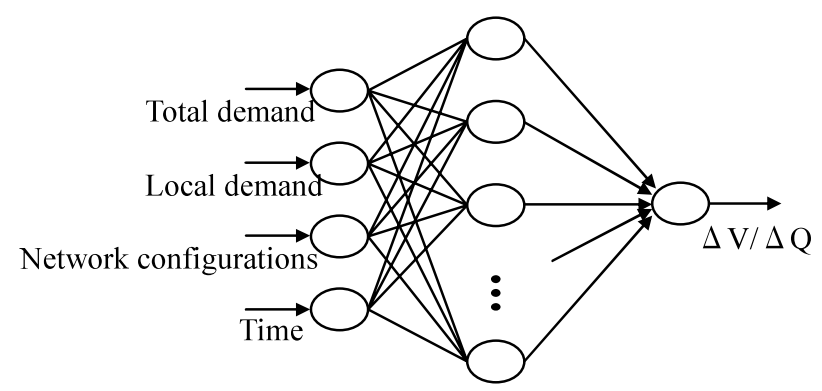

図 $6 \Delta \mathrm{V} / \Delta \mathrm{Q}$ 特性の推定に使用する $\mathrm{NN}$ 構成

Fig. 6. Structure of neural network for $\Delta \mathrm{V} / \Delta \mathrm{Q}$ estimation.

\section{4. 地域需要予測モデルの選定}

$\Delta \mathrm{V} / \Delta \mathrm{Q}$ 特性は，(1)系統並列発電機量と運転状況，(2)系統 構成 (放射状系統/ループ状系統等)，(3)需要構成，(4)送電 線潮流状況，(5)電圧・無効電力設備配置状態，などに左右 される。従って, 系統電圧変動はこれら関連データの時系 列変化の反映にほかならない。前章で述べた NN 法による $\Delta \mathrm{V} / \Delta \mathrm{Q}$ 取得の検証では地域総需要時系列データを手作業 で入力した。本章はこの地域総需要時系列データを NN 法 により予測し，データを自動的に受け渡すことを意図して いる。

$\mathrm{NN}$ 法による需要想定の論文は種々あるが, 本論文か㳔象 とする日間需要曲線予測に関する参考論文は文献 (7)〜 (9) 等がある。本論文が目的とする当日運用の地域日負荷曲線 予測は文献 (9) である。しかし，これは中給の当日運用計 画データ用で，产の使用法はオフラインである。我々が意 图するものは地域需要を想定する手法を分散配置された発 変電所 AVQR に内蔵させ，リアルタイムで自動的に応動さ せるものである。従って使用する入力データの種類と出力 データの要求精度も異なる。本論文では $\langle 4 \cdot 1\rangle \sim\langle 4 \cdot 8\rangle$ 節ま で 8 種類の NN モデルを思考錯誤で繰り返しながら検討と 改良を重ね，最終的には検討 8 のモデルを使用することに した。
シミュレーションに使用したデータは岩手支店需要を参 考にした值を用いた。得られたデータが各季節の代表的な データー日分であったため，得られたデータをもとに夏の データ 3 か月分を作った。予測期間としてはお盆などの特 異日を除いた一般的な日曜日から土曜日までを模擬し予測 を行った。

〈4: 1〉 検討 1: 基礎モデル 本研究で使用する 0.5 1 時間先の需要予測では予測対象時間帯から $0.5 \sim 1$ 時間前 の実績データを使用できる利点がある。入力データとして は, 予測する時間に得られる地域需要データ (Load), 天候 データ (Weather), 気温データ (Temperature), 時間デー タ (Time) である。また, 平日, 土曜日, 日曜日の曜日を 識別する土日フラグデータ (Day-of-week Flag) を使用す る。これらの入カデータから $0.5 \sim 1$ 時間先の地域需要予測 を行う 6 入力 1 出力の構成である。学習データは予測対象 日から近過去 2 週間のデータを使用する。この検討の NN 構成を図 7 に示す。

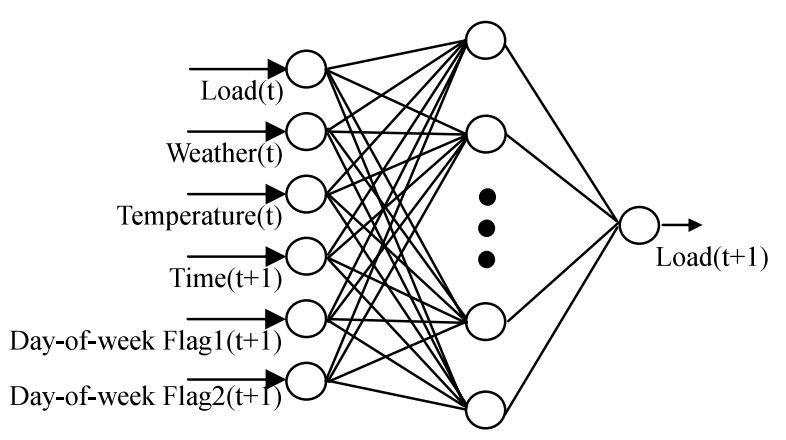

図 7 NN の構成

Fig. 7. Neural network structure.

表 1 検討 1 の予測結果

Table 1. Result of case 1 .

\begin{tabular}{|c|c|c|}
\hline & MAPE of weekday[\%] & MAPE of one week [\%] \\
\hline Case 1 & 1.416 & 1.558 \\
\hline
\end{tabular}

予測結果を比較するために平均絶対誤差率 (MAPE) を 使用する。

$$
\text { MAPE }=\sum_{i}^{n} \frac{\mid \text { actual }_{i}-\text { forecast }_{i} \mid / \text { actual }_{i}}{n} \times 100
$$

actual $_{\mathrm{i}} ; \mathrm{i}$ 時の実績値，

forecast $t_{i} ; i$ 時の予測值 ,

$\mathrm{n}$; 予測シミュレーションの個数

月曜日から金曜日までの平均絶対誤差率を MAPE of weekday，日曜日から土曜日までの平均絶対誤差率を MAPE of one week として表 1 に記載する。

〈4 2〉 検討 2: 気象データにおける予測值と実績值の使 用による比較 $\langle 4 \cdot 1\rangle$ 節では気象関連データに実績值を 用いたが，ここでは気象関連の予測值データを毎時間ごと に気温 $(t+1)$ を 24 時間分予測し，地域総需要を予測する 方法について検討を行った。気象庁では 1 時間毎の気温， 
天候は予報していない。このため次のようにNNを用いて 24 時間の気温データを作り出す。入力データには前日に得 られた最高気温, 最低気温, 天候の 3 入力とし，各時間の 気温を予測する (図 8 )。

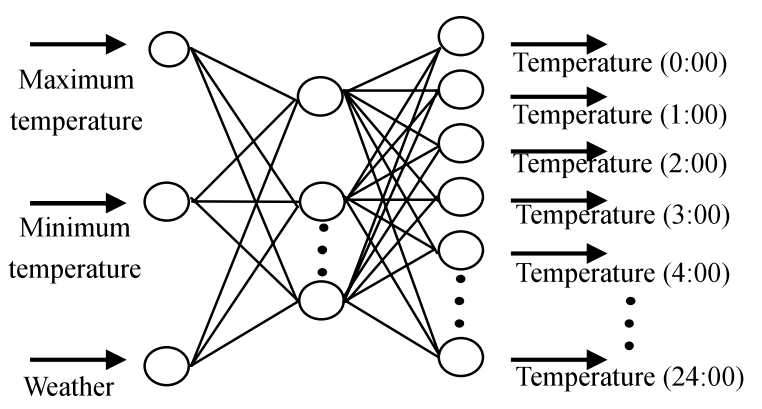

図 8 気温予測システム

Fig. 8. Temperature forecasting system.

表 2 検討 2 の予測結果

Table 2. Result of case 2 .

\begin{tabular}{|l|c|c|}
\hline & MAPE of weekday[\%] & MAPE of one week[\%] \\
\hline Case 2 & 1.451 & 1.664 \\
\hline
\end{tabular}

通常，1 時間程度では天候は变わらないので, 気象庁か ら予報される 3 時間毎の予報を用いる。表 1 と表 2 を比較 すると検討 1 検討 2 の結果は予測精度にあまり差がないこ とを示している。図 9 の結果は気象予報が外れると予測値 を用いた検討 2 は予測精度が悪化することを示している。 しかし，気象関連データに実績值を使うと気象予報が外れ た場合でもある程度適切な予測ができることを確認した。

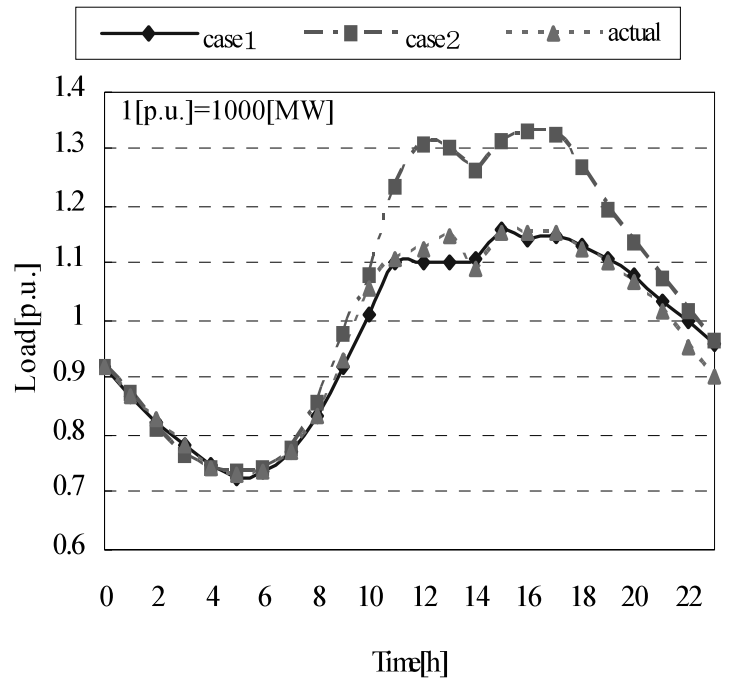

図 9 気象予報が外れた場合の予測事例

Fig. 9. Forecasting result for the failed weather forecast.

〈4 3〉検討 3: 昨年度近似データの抽出モデル 単純 に近過去 2 週間のデータのみで学習すると，季節の移り変 わりによる気温変化に遅れが生じることや，気象条件の近 似するデータが含まれないことがある。この対策としては 昨年度データを学習データとして使用する方法が考えられ
る。しかし，当該年度と同じ暦日の前年度データでは曜日， 気象条件, 景気トレンド等が異なるので光のままでは使え ない。従って，これらのデータを何らかの方法で当該年度 暦日に相当するデータに補正した上で使用することが不可 欠である。

本手法では補正誤差を含む不要なデータでの学習を防止 するため予測対象日と気象条件の近似する前年度実績デー タを自己組織化特徵マップによって抽出する。入力データ としては最高気温, 最低気温, 天候の 3 入力とする (図 10)。 補正した前年度データを学習データとして使用し, 検討 1 の手法と組み合わせた結果を表 3 に示す。

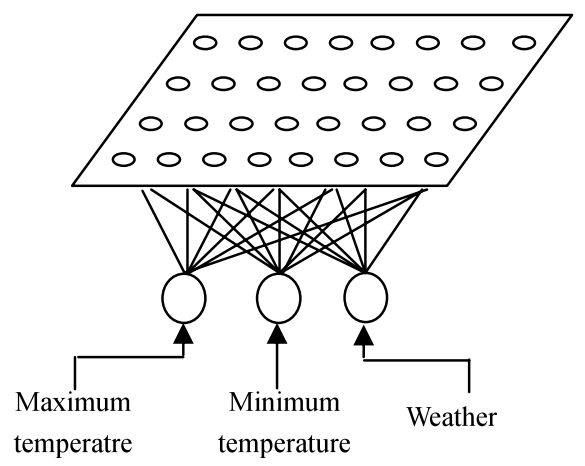

図 10 昨年度データ抽出概念

Fig. 10. Concept of extracting last data.

表 3 検討 3 の予測結果

Table 3. Result of case 3 .

\begin{tabular}{|c|c|c|}
\hline & MAPE of weekday[\%] & MAPE of one week[\%] \\
\hline Case 3 & 1.335 & 1.427 \\
\hline
\end{tabular}

〈4４〉検討 4: 平日の曜日特性を考慮したモデル＼cjkstart平 日の地域需要曲線では月曜日から金曜日まで負荷の立ち上 がりに若干の差がある。週初めの月曜日には負荷の立ち上 がりが鈍る傾向があり，金曜日に近づくにつれ徐々に負荷 の立ち上がりが鋭くなる。また地域需要は前日の地域需要 が高いと次の日も光の影響を受けて大きくなる傾向がある。 平日の負荷立ち上がり傾向は当日内の全時間帯に同一の傾 向が観測される。従って, $\mathrm{n}$ 時間前までの地域総需要を $\mathrm{NN}$ の入力データとして適切に学習させると負荷の立ち上がり 傾向を的確に把握できる可能性を示唆している。この場合 $\mathrm{n}$ の值を如何に決めるかが課題となる。データに誤差が含 まれていない条件でシミュレーションにより検討した結果， $\mathrm{n}$ 時間前データ入力数を増やすと MAPE が小さくなった (図 11)。

しかし，実際のデータは説明の難しいランダム誤差のよ うな変動が含まれるため $\mathrm{n}$ 時間前入力デー夕数を増やすと 予測精度が悪化することも予想される。光こで需要量に対 して最大で $5 \%$ 程度の正規乱数を加えたケースについても検 討した。図 12 は乱数を含むデータでの $\mathrm{n}$ 時間前までのデー タ入力数と予測精度の関係を示す。 2 時間前までのデータ を使用すると良い傾向が得られたので 2 時間前までの需要 を入力した。この検討結果を図 12 および表 4 に示す。 


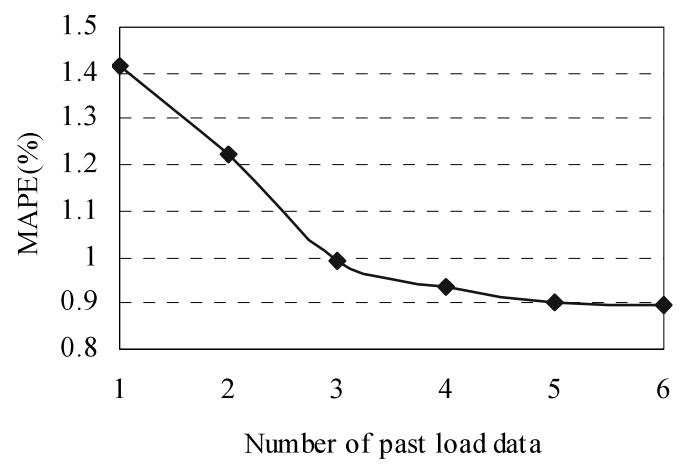

図 11 需要入力数と予測誤差の関係

Fig. 11. Relationship between input load number and MAPE.

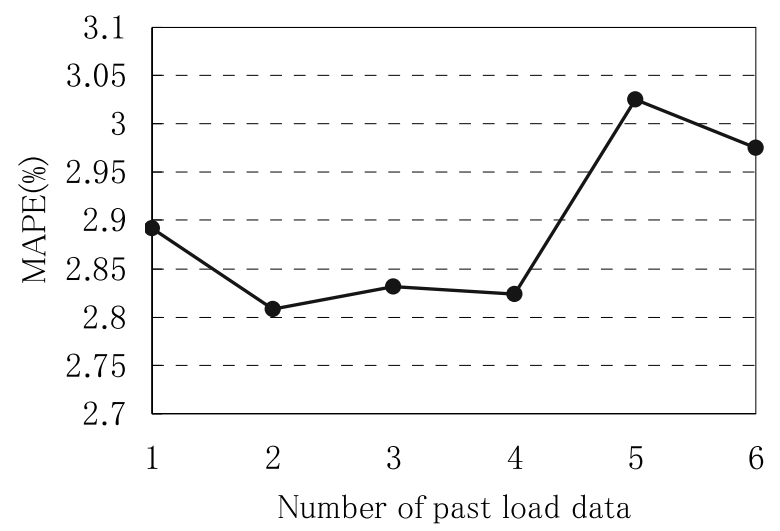

図 12 乱数を含んだ場合の需要入力数と予測誤差 の関係

Fig. 12. Relationship between input load number and MAPE including random number.

表 4 検討 4 の予測結果

Table $4 . \quad$ Result of the case 4.

\begin{tabular}{|c|c|c|}
\hline & MAPE of weekday[\%] & MAPE of one week[\%] \\
\hline Case 4 & 1.226 & 1.433 \\
\hline
\end{tabular}

〈4 5〉 検討 5: 気象予報外れを考慮したモデル 翌日 の地域需要予測を行う手法としては本研究のように出力層 を 1 ユニットにして 1 時間ずつ予測する方法と出力層を 24 ユニットにして一括して予測する方法がある。後者は最高 気温，最低気温，天候データなど前日に得られる予報デー タから予測を行う手法である。出力層 24 ユニットで予測 を行う方が地域需要曲線自体を学習することから平日にお ける予測精度は高い傾向にある。しかし需要曲線の異なる 土曜日, 日曜日に予測精度が悪化した。また予測値から予 測を行うため気象予報の外れた場合に精度が悪化すること や，学習データに誤差などが含まれると予測精度が急激に 低下する傾向がある。この欠点を取り除く予測手法として 検討 5 では出力層 24 ユニットで出力した結果を 1 時間先 需要予測 (検討 1 ) 学習データの 1 つとして使用する。学 習データの気温データは図 8 の NN で求め, 天候データに 関しては 3 時間予報を使用する。予測されたデータを学習 データの 1 つとして使うことで，当日の気象が気象予報に 近いときには 24 ユニットの出力に近い予測值が得られる。 気象予報が外れた時は近過去 2 週間データと 24 ユニット出
力を反映した予測值が得られ, 汎化能力の高い予測システ ムが構成できる。出力層 24 ユニットの NN の構成を図 13 のようにした。また出力層 24 ユニットの結果と検討 5 の 結果を表 5 に示す。

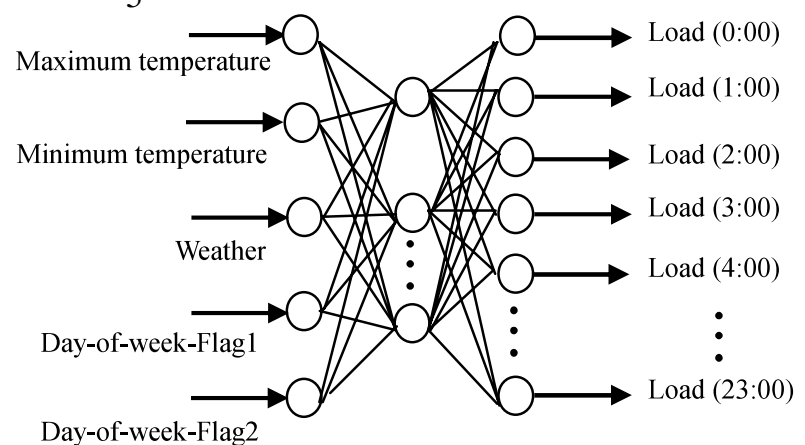

図 13 出力層 24 ユニット型 NN の構成

Fig. 13. Neural network structure by 24 output unit type.

表 5 検討 5 の予測結果

Table 5. Results of 24 output unit type and case 5.

\begin{tabular}{|c|c|c|}
\hline & MAPE of weekday[\%] & MAPE of one week[\%] \\
\hline 24 output unit type & 0.751 & 1.718 \\
\hline Case 5 & 1.258 & 1.527 \\
\hline
\end{tabular}

〈4 6〉 検討 6: 時間データシフトの効果 ここではよ り適切な学習可能なデータ入力として, 時間帯の関係につ いて検討した。平日の需要と時間の関係に注目すると時間 が 0 時から始まり 5 時までは減少が続く。5 時以降に注目 すると朝の立ち上がりが始まり需要か増える。12 時頃に昼 休みに入るため減少し，1 時から 2 時に昼休みが終わり増 加する。17 時から再び咸少するというサイクルがある。需 要の増加, 減少に転じる点において予測精度の悪化が生じ るため，この増加減を減らすように時間データを入力すれ ば予測精度が向上すると考えた。具体的には 0 時〜24 時と 入力していた時間データを 5 時〜翌日 5 時にシフトするこ とで需要の下降から上昇の変化極值数を減らすことができ る Customized time (Ct) を入力した (図 14)。Ctデータ を入力した結果を表 6 に示す。

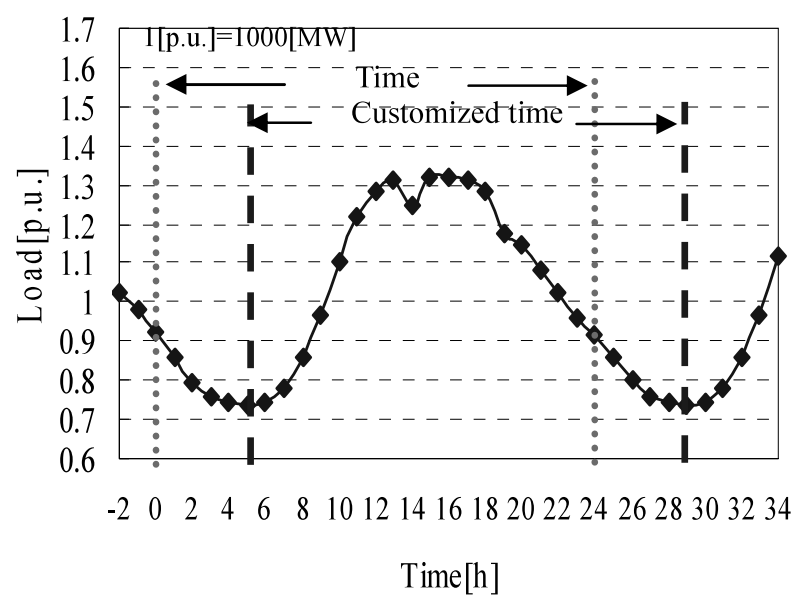

図 14 時間入力の改良概念

Fig. 14. Concept of customized time. 
表 6 検討 6 の予測結果

Table 6. Result of case 6.

\begin{tabular}{|c|c|c|}
\hline & MAPE of weekday[\%] & MAPE of one week[\%] \\
\hline Case 6 & 1.549 & 1.689 \\
\hline
\end{tabular}

〈4 7〉検討 7: 昼休み予測誤差改良モデル 検討 6 と 検討 1 を比べ, 時間を改良すると予測精度が悪化した。こ の原因は時間を適正化すると昼休みの減少を適切に学習で きなくなり，予測精度が悪化したことが分かった。この対 策として月曜日から土曜日まで観測される昼休みの急激な 需要の減少時間帯への入力データとして -1 , さらに日曜日 における急激な需要の増加か観測される 20 時に +1 を入 力, 光れ以外は 0 を入力する Lunch-trough, Sunday-peak データ (以下 LS データ) の入力を考えた（図 15)。この LS データを入力した検討 7 , 検討 6 と検討 7 を組み合わせ たシミュレーション結果を表 7 に示す。LS データを使用 することで予測精度が向上できることが確認できる。また 表 7 から検討 6 の時間シフトを組み合わせて使うことで予 測精度がさらに向上する傾向が得られた。

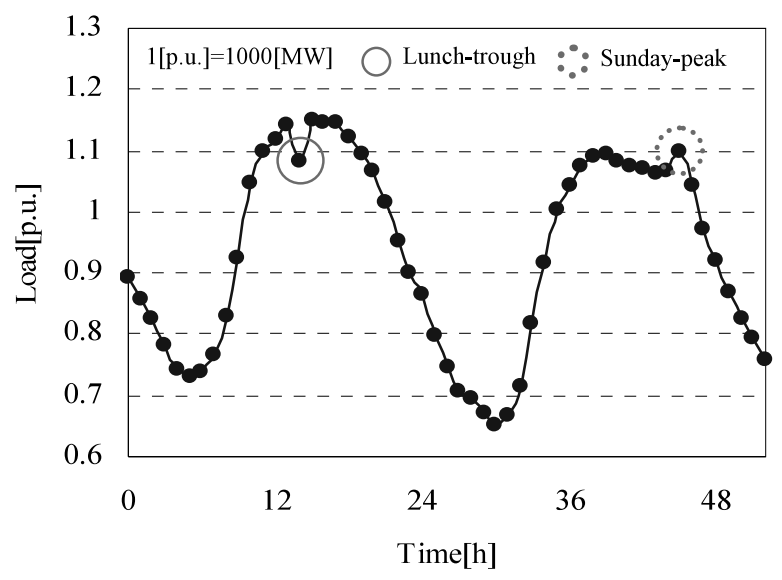

図 15 昼休みの需要減少と日曜日の需要増加事例

Fig. 15. The case of lunch-trough and Sunday-peak.

表 7 検討 7 , 検討 $6 \&$ 検討 7 の予測結果

Table 7. Results of case 6 , case 6 \&case 7 .

\begin{tabular}{|c|c|c|}
\hline & MAPE of weekday[\%] & MAPE of one week[\%] \\
\hline Case 7 & 1.191 & 1.266 \\
\hline Case 6 \& Case 7 & 1.156 & 1.238 \\
\hline
\end{tabular}

〈4:8〉検討 8: 最終改良モデル これまでの検討結果 で検討 1 より予測精度の向上か確認できた手法を組み合わ せたものを改良モデルとする。組み合わせた手法としては， 検討 1 をべースとし，検討 3 ，検討 4 ，検討 5 ，検討 6 ，検 討 7 を組み合わせた。NN の構成，使用する学習データを 図 16 に示す。予測精度に関しては表 8 に示す通り，適切 な予測ができた。図 17 は改良手法により日曜日〜土曜日 まで予測した際の実績值と予測值の関係を示す。

この時の平均絶対誤差率の時間的推移を図 18 に示す。

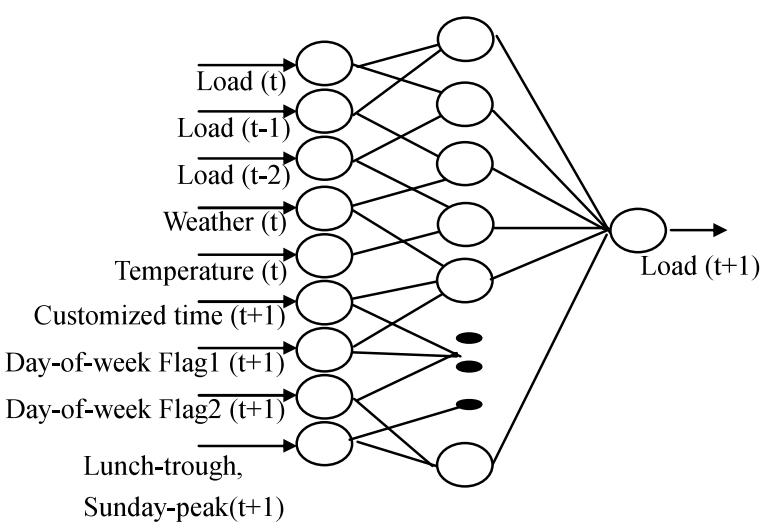

Learning: data of nearest 2 weeks, selected data of last year and forecast data of tomorrow

图 $16 \mathrm{NN}$ の構成

Fig. 16. NN structure of improved method.

表 8 検討 8 の予測結果

Table 8. Result of improved method.

\begin{tabular}{|c|c|c|}
\hline & MAPE of weekday[\%] & MAPE of one week[\%] \\
\hline Improved method & 0.719 & 1.072 \\
\hline
\end{tabular}

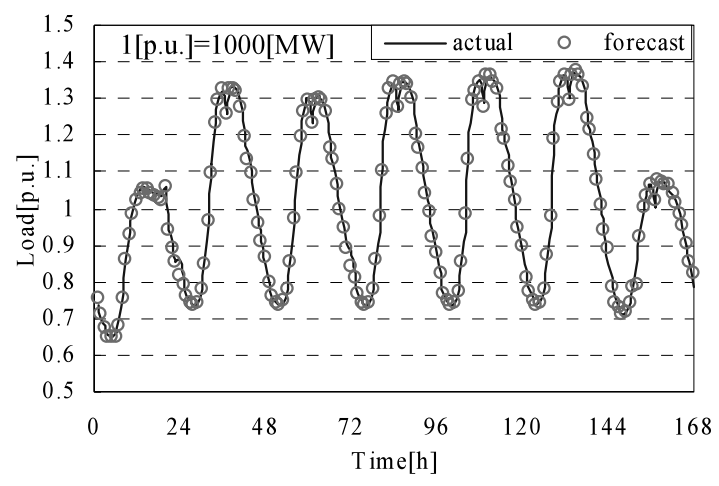

图 17 改良モデルによる予測事例

Fig. 17. The test case of improved method.

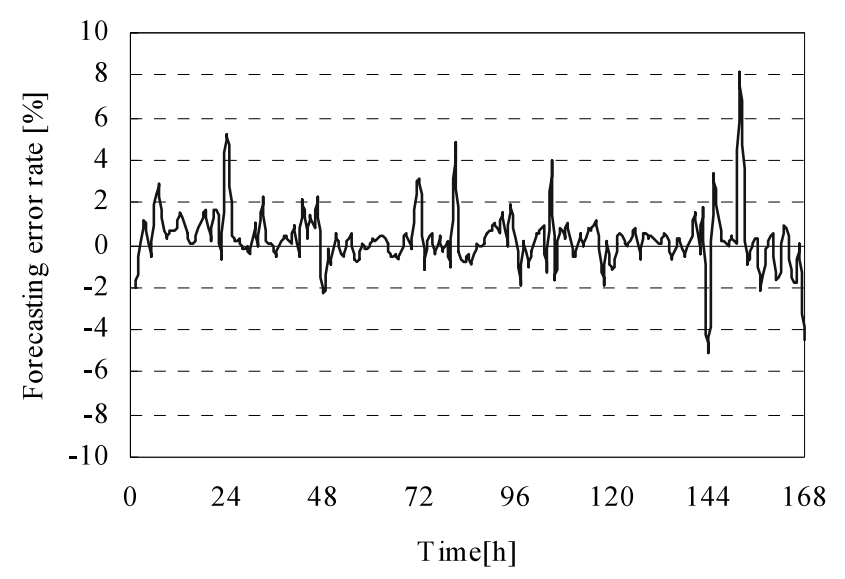

图 18 改良モデルによる誤差率の時間的推移

Fig. 18. Forecasting error rate of improved method. 


\section{5. まとめ}

本論文は電力自由化の進展による分散電源導入量の増大 に伴う二次系統および配電系統の電圧無効電力制御の協調 と電圧不安定問題に対処可能な自律分散制御機能を強化し た次世代電圧無効電力制御システム構築のために必要な構

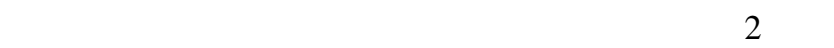
手法を提案した。

・電気所の電圧無効電力制御装置を高度化にインテリジェ ント化した次世代自律分散型 AVQR の基本設計概念を 明らかにした。

・系統電圧特性をオンラインリアルタイムで推定するた めにローカルの $0.5 \sim 1$ 時間先の需要想定を NN 法で実 施する方法を開発した。

ローカル系統の電圧無効電力特性をリアルタイムで推定 するためには, ローカル系統内で稼動中の分散電源量を推 定する機能が必要である。稼動中の分散電源量の推定手法 については目下，検討中である。これらの機能を開発すれ ば，高精度な自律分散型電圧無効電力制御が可能となる。 なお，今後，地域需要予測システムを実系統に適用する場 合 , 地域ごとの特性を考慮したチューニングが必要である。 また，今回開発した地域需要予測システムを一部拡張する ことにより中給や支店給システムへの転用も可能である。

(平成 17 年 3 月 4 日受付, 平成 17 年 6 月 15 日再受付)

文献

(1) T. Minakawa: "Technological Renovation on Electric Utilities in USA (No.3)," Technology Bulletin of Tohoku Electric Power Co., No.35 (1971) (in Japanese)

皆川 保: 「海外出張報告 (光の 3)」, 東北電力研究期報, No.35 (1971)

(2) T. Minakawa, Y. Ichikawa, S. Hayashi, K. Hirayama, T. Sogabe, and T. Toyozumi: "Limiting the movements of transformer taps to control voltage and reactive power", 11th PSCC, Avignon, France (1993)

(3) S. Hayashi, K. Hirayama, T. Sogabe, T. Toyozumi, T. Minakawa, and Y. Ichikawa: "Fuzzy expert for main transformer's tap Changer to control voltage and reactive power", T. IEE Japan, Vol.115-B, No.11, pp.1337-1442 (1995-11)

( 4 ) H. Lerebvre, D. Fragnier, J. Boussion, P. Mallet, and M. Bulot: "Advantages of Coordinated Secondary Voltage Control in a Deregulated Environment", CIGRE, Report 39-208 (2000)

( 5 ) T. Minakawa, R. Yokoyama, E. Momma, and J. Sugimoto: "Advanced autonomous transformer's tap changer control sysyem for coordinated secondary voltage control in EHV power systems", Catalog No.03EX719C, ISBN 0-7803-7967-5/03/ (CDROM), 2003 IEEE Bologna Power Tech, Bologna, Italy (2003-6)

(6) E. Momma, O. Suzuki, T. Minakawa, and T. Yamaguchi: "Basic studies on Distributed Autonomous Voltage and Reactive Power Control System using AI Method", The Papers of Technical Meeting on PE \& PSE, IEE Japan, PE-03-2123/PSE-03-134, pp.13-18 (2003) (in Japanese) 門間栄吉・鈴木 修・皆川 保・山口哲司 : 「 $\mathrm{AI}$ 技術を適用した自 律分散型電圧無効電力制御方式の基礎研究」, 電気学会電力技術 ·系 統技術合同研資, PE-03-123/PSE-03-134, pp.13-18 (2003)

( 7 ) T. Matsui, T. Iizuka, and Y. Ueki: "Daily Load curve Forecasting using Recurrent Neural Network", The Papers of Technical Meeting on PE \& PES, IEE Japan, PE-96-21/PSE, pp.79-88 (1996) (in Japanese)

松井哲郎・飯坂達也・植木芳照：「リカレントネットワークを適用 した日負荷曲線予測」, 電気学会電力技術・系統技術合同研資, PE-9621/PSE-96-21, pp.79-88 (1996)

( 8 ) T. Senjyu,H. Takara, K. Uezato, and T. Funabashi: "Next day Load Curve Forecasting Novel Neural Network Structure", The Papers of Technical Meeting on PE \& PES, IEE Japan, PE-01-67/PSE-01-61, pp.25-30 (2001) (in Japanese)

千住智信・高良仁之・上里勝実・船橋俊久 : 「ニューラルネットワー ク補正法を用いた翌日負荷曲線予測」, 電気学会電力技術・系統技術 合同研資, PE-01-67/PSE-01-61, pp.25-30 (2001)

(9) O. Ishioka, Y. Sato, T. Ishihara, Y. Ueki, T. Matsui, and T. Iizaka: "Development of Electric Load Forecasting System using Neural Networks", T. IEE Japan, Vol.120-B, No.12, pp.1550-1557 (2000-12) (in Japanese)

石岡 修·佐藤佳彦・石原 徹・植木芳照・松井哲郎・飯坂達也 : $\ulcorner\mathrm{NN}$ 応用電力需要予測システムの開発」, 電学論 $\mathrm{B}, \mathbf{1 2 0}, 12, \mathrm{pp} .1550-1557$ (2000-12)

(10) O. Suzuki, T. Minakawa, R. Yokoyama, and H. Tanaka: "Advanced Intelligent voltage control Systems Coordinating Main and Local Power Systems", Proc. of IEEE St. Petersburg 2005 Power Tech., No.223, St. Petersburg, Russia (2005-6)

鈴 木

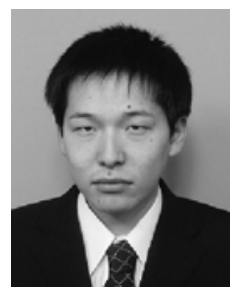

修 (学生員) 1981 年 12 月 30 日生。2004 年 3 月東 北学院大学工学部電気工学科卒業。2004 年 4 月 東北学院大学大学院工学研究科博士課程前期に進 学, 現在に至る。主に知識処理 $(\mathrm{AI})$ 工学の電力 系統制御への応用に関する研究に従事。電気学会 学生会員。
吳 国 紅 (正員) 1969 年 9 月 26 日生。1989 年 9 月天津

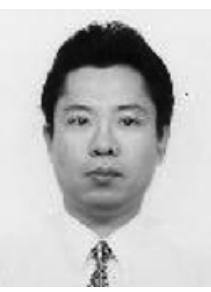
大学電気工学科 (中国) 卒業 (B.S.)。1994 年同 大学大学院修士課程修了 (M.S.)。1997 年東京大 学および天津大学共同連繋協定に基づき大学院博 東京大学大学院で JSPS 助手と協力研究員。2001 年 4 月〜2005 年 3 月東北大学工学部助手。2005 士課程修了 (Ph.D.)。1998 年 4 月〜2001 年 3 月 年 4 月より東北学院大学工学部電気情報工学科講 師。電力系統安定度, FACTS および超電導応用, HVDC, 新エネル ギーシステム等研究に従事。電気学会会員, 工学博士。

皆 川保 (正員) 1935 年 1 月 2 日生。1959 年 3 月早稲田

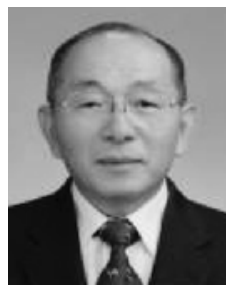
大学第一理工学部電気工学科卒業。同年 4 月東北 電力 (株) 入社。発変電, 系統計画・運用, 研究 等の部門に従事。1968〜1969 米国 GE 社の PSEC に派遣され，系統運用自動化・系統計画手法の調 査, 研究開発に従事, 1994 年 7 月東北コンピュー タサービス (株) 出向。1995 年 4 月東北学院大 学非常勤講師を兼務, 1997 年 4 月東北学院大学 教授。工学博士。電気学会会員, IEEE 会員, CIGRE 会員。 